\title{
前立腺肥大症に対する経直腸式温熱療法の意義
}

\begin{tabular}{|c|c|c|c|c|c|c|c|}
\hline \multicolumn{8}{|c|}{ 日本大学医学部泌尿器科学教室 } \\
\hline 岡田 & 清己 & 吉田 & 利夫 & 遠藤 & 真琴 & 青木 & 豊 \\
\hline 池谷 & 知格 & 吉川 & 哲夫 & 平方 & 仁 & 大井 & 知孝 \\
\hline 小林 & 正喜 & 清滝 & 修二 & 佐藤 & 安男 & & \\
\hline
\end{tabular}

\section{SIGNIFICANCE OF TRANSRECTAL HYPERTHERMIA FOR THE TREATMENT OF BENIGN PROSTATIC HYPERPLASIA}

\author{
Kiyoki Okada, Toshio Yoshida, Makoto Endo, Yutaka Aoki, Tomonori Ikeya, \\ Tetsuo Yoshikawa, Hitoshi Hirakata, Tomonori Ohi, Masaki Kobayashi, \\ Shuji Kiyotaki and Yasuo Satoh \\ Department of Urology, Nihon University School of Medicine
}

Though the local hyperethermia for the management of benign prostatic hyperplasia has drawn much attention as one non-surgical treatment, no definite conclusion could yet be obtained in terms of the efficacy. In this study local hyperthermia was induced in evaluable 33 cases with benign prostatic hyperplasia using Primus, and the effectiveness of this modality of treatment was investigated by analysing the subjective and objective response following hyperthermia.

The prostate was heated transrectally up to $43^{\circ} \mathrm{C}$ with $915 \mathrm{MHz}$ microwave for one hour. Hyperthermia was carried out twice a week for ten times for the sake of thermotolerance. Urinanry obstructive symptoms were divided into diurnal and nocturnal frequency, urinary urgency, the degree of urinary stream, hesitancy and dribbling. Each symptom was described before and after the treatment according to the scoring system. Moreover, objective changes of urinary flow and prostatic size were estimated by the residual urine volume, uroflometry, rectal palpation of the prostate and echography.

Hyperthermic treatment improved urinary flow markedly, but no appreciable alteration could be observed as to the size of the prostate. The overall efficacy, including subjective and objective response, could be summarized as $37 \%$ of effectiveness, and $33 \%$ of slight effectiveness, that is, $70 \%$ of effective ratio. As to the side effect, anal pain was noted in few cases of the present series. Therefore, transrectal hyperthermia may be a suitable modality for non-surgical treatment of benign prostatic hyperplasia.

Key words: benign prostatic hypertrophy, hyperthermia, microwave

\footnotetext{
要旨：前立腺肥大症に対する局所温熱療法は非観血療法の一つとして注目されているが，いまだその効 果に関しては定まった評価はなされていない。このことより，われわれは前立腺温熱治療器“プリモス” を用いて33例の前立腺肥大症症例に温熱療法を試み, 自覚的症状, 他覚的所見の変化を客観的に分析し, その効果を判定した。

治療方法は経直腸式に前立腺を 1 時間加温し, 週 2 回, 計10回施行した. 自覚的改善度判定のために 各症状に点数を付け，その症状が施行前後でどのように変化するかを記載した。ささらに，他覚的には残 尿測定，尿流量測定により尿流の変化を，前立腺触診，エコーにて前立腺の大きさの変化を測定した。 その結果, 施行前後において著明な尿流の変化がみられたが, 前立腺の大きさには変化がみられなかっ た．副作用を含めた総合評価では有用 $37 \%$ ，やや有用 $33 \%$ で，70\%の有用率が得られた．主な副作用と しては肚門部の疼痛であった。以上より, 前立腺局所温熱療法は前立腺肥大症の非観血的療法とし有意
} 
義な治療法であるとの結論を得た。

キーワード：前立腺肥大症, 温熱療法, 超短波

\section{I. 緒 言}

癌が温熱により縮小するといら事実は古くから臨床 的に認められていだ1).しかし，癌に対して温熱がどの ように作用して, 抗腫瘍効果を発揮するかといら機構 は最近になってようやく解明されてきた。すなわち， 癌細胞それ自身が温熱感受性を有していること ${ }^{2)}$ お よび腫瘍部に扣ける血流動態が正常組織に比べ温熱で 低下し壊死に陷いるため ${ }^{3)}$ ，と解釈される。このような 理論的背景があるにもかかわらず，臨床的にはその副 作用から限定された疾患で, また種々の工夫された手 段を用いて温熱療法が細々と行われてきたにすぎな い。れわれも膀胱腫瘍に対して温水療法といら手段 で温熱療法を行ったが，その効果は表在性腫瘍に限ら れるという結果であった4).

最近, 電磁波による局所温熱治療器が開発され, 深 部治療が可能となり, 進行性前立腺癌の治療にも応用 されてきた。それによると前立腺癌は温熱寮法と放射 線療法, ホルモン療法の併用により腫湯縮小を示した が5)，生存率をあげるまでには至らなかったという6)。

しかし, その治療経過中に前立腺癌に伴ら種々の排尿 異常としての局所症状が著しく改善されたことが注目 された，すなわち，同じ前立腺疾患である前立腺肥大 症の局所症状もまた温熱療法により改善されるのでは ないかと期待された。そのことより諸外国に䗆いて前 立腺肥大症の温熱療法が盛んに試みられ7), その有用 性に関して発表された。

一方, 前立腺肥大症は高齢者に発生する疾患である. しばしば重篤な合併症のため, 手術不可能な症例も存 在するため, 非観血的な手段による治療法の確立が望 まれていた。すでに非観血的治療としてバルーン拡張 術が行われているが8), 長期 follow up の予後は検討中 である，以上のことより，前立腺肥大症に対する温熱 療法の効果を判定することは有意義なことと考えた。 今回, 前立腺肥大症患者に温熱療法を行ったときの自 覚的症状, 他覚的所見の改善度, 括よび全般的な有用 性に関して検討したので報告する。

\section{II. 対象および方法}

\section{1. 対象}

対象症例の条件としては，(1) 触診所見, 生化学検 查, レントゲン検査, 経直腸式前立腺超音波断層像 (transrectal ultrasonography 以下, TRUS) より前立
腺肥大症と診断され，(2) 尿路閉塞症状が存在し，(3) 前立腺肥大症の未治療例, または既治療に拈ける無効 例，であること．

前立腺肥大症と診断されても以下の患者は原則とし て除外した。（1）経直腸式前立腺局所温熱療法（transrectal prostatic hyperthermia 以下, TRPHT) に上 り危険が生ずる可能性がある症例，（2）精神的な面で 施行が困難と思われる症例, (3) 大きな膀脂喤室, 神 経因性膀胼, 膀胼䫋部硬化症, 尿道狭窄など前立腺肥 大症以外による排尿障害患者, (4) 血清クレアチニン $2.0 \mathrm{mg} / \mathrm{dl}$ 以上の腎機能低下症例，（5）急性尿路感染 症，（6）慢性前立腺炎を合併している症例，（7）装置 を挿入する直腸が治療を行らのに不適当な状態と思わ れるとき，(8) PAP, PA， $\gamma$-sm がそれぞれ $3.0 \mathrm{ng} / \mathrm{ml}$, $3.6 \mathrm{ng} / \mathrm{ml}, 4.0 \mathrm{mg} / \mathrm{ml}$ 以上を示し前立腺癌が疑われる 場合.

\section{2. 使用機器}

前立腺肥大症治療用高周波温熱治療装置である “プ リモス”（テクノマティクス社製）を用いた（図 1). 本機器は，（1）高周波電流発生装置, (2) アプリケー タ，（3）冷却装置，（4）温度測定装置，（5）ディスプ レイ抢よびュンピュータ装置からなる.(1)の高周波電 流発生装置より $915 \mathrm{MHz}$ の高周波を発生する. 出力は

図 1 温熱治療装置. 左は本体, 右はアプリケータ
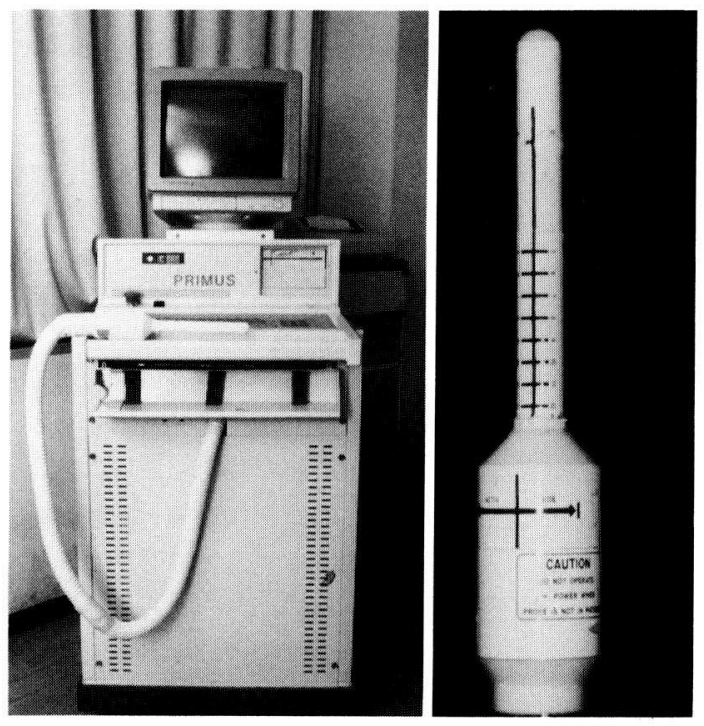


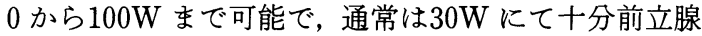
を加温することができる（2）アプリヶータは直腸内 に挿入する器具で，必ず表面はゴムサックをかぶせ， 滑液をほどこし，直腸前壁に密着するようにして插入 する。アプリケータには目盛がついており，あらかじ め触診により前立腺の位置を定める(図 1)。その内部 にはアンテナがありアプリヶータに対して直角に高周 波が放射される．さらに前立腺以外に照射されるのを 防ぐためにレフレクターが取付けられている。（3）冷 却装置としては, そのアプリケータの表面にクーリン グ回路があり，水冷にてアプリケータの表面が高温に なることを防いでいる。（4）温度測定装置は 5 チャン ネルあり, 各所で温度測定が出来るようになっている. そのらちの 3 つは直腸粘膜の温度を測定し, 設定以上 の温度になると自動的に中断し，熱による損傷を防い でいる。 また，前立腺内，尿道内にセンサーを捜入し， 温度を測定する装置も併設されている。しかし，われ われは患者に対する侵襲は最小限にすべきと考兄, 臨 床例では使用していない.すでに pilot studyによる動 物実験の結果より想定温度を設定し,さらにコン ピュータシュミレーションにより前立腺内温度が $43^{\circ} \mathrm{C}$ になるよらな加温出力を定めている。（5）その他，監 視用の TVモニター, 装置全体の制御, 記録のための コンピュータ，プリンターが含まれている。

\section{3. 施行法}

患者はやや股を開いた状態で仰臥位となる。通常， 麻酔は行わない。アプリケータを直腸に挿入し適正な 位置に固定する，時間は 1 時間であるが，実際には温 度上昇に時間がかかるため, 約80分は必要である。温 度は前立腺内が $43^{\circ} \mathrm{C}$ になよらに設定し, 直腸表面は $36^{\circ} \mathrm{C}$ 以下にする。これを週 2 回, 合計 10 回行らことを 原則とする. 自覚的点数（後述）は毎日でも行えるが, 5 回，10回終了時にまとめて評価する。他覚的所見は 10 回終了時に検査し，その变化を記録する.

\section{4. 観察項目}

(1) 完全な病歴と理学的所見（脈拍, 血压, 体温,

体重, 直腸診, 残尿量) を施行前後に行う.

（2）尿検査，血液検査 (CBC, PAP, PA， $\gamma$-sm) は施行前と最終治療後 1 週以内に行了。

（3）ウロダイナミックス, TRUS, 尿道膀胼造影, 排泄性腎孟造影などを施行前と最終治療 1 週以内に行 5.

（4）生検は悪性が疑われた時に行う.

5. 効果判定評価方法
自覚的評価と他覚的検查による方法が行われた。自 覚的な症状改善度を少しでも客観的にするために, 以 下のごとく各症状により点数を定めた.

(1) 自覚的症状別点数

a. 昼間排尿回数

$0: 1 \sim 4$ 回/日, $1: 5 \sim 7$ 回/日, $2: 8 \sim 12$ 回/ 日, $3: 13$ 回/日以上

b. 夜間排尿回数

$0: 0$ 回/日, $1: 1$ 回/日, $2: 2 \sim 3$ 回/日, 3 : 4 回/日以上

c. 尿意逼迫感

$0 ：$ 無し， $1 ：$ 時々感じる, $2 ：$ 頻回に感じる, ま れに失禁する， 3 ：つねに尿意を感じ，時々失禁する.

d. 尿線の状態

0 : 良好, 1 : 尿線の減弱, 2 : 尿線の太さと強さ はつねに减弱している， 3 : 排尿において非常な努力 を要し, 尿線は途絶する。

e. 排尿遷延度

0 ：まれに，排尿遷延する(約 $20 \%$ 以下)，1：時々 排尿遷延する(約20～50\%)，2：頻回に排尿遷延する (約 $50 \%$ 以上，乙かし 1 分以内)， 3 ：つねに排尿遷延 する（1 分かそれ以上).

f. 排尿苒延度

0 ：まれに，排尿苒延する，1：時々排尿䓦延する. 2 : 頻回に排尿苯延する， 3 : つねに排尿䓦延する。

これらを合計すれば 0 点から18点をで分布すること になる. 自覚的改善度の判定には TRPHT 施行前後に おいて $50 \%$ 以上低下したときは自覚著効，50\%から $25 \%$ までは自覚有効, $25 \%$ から0\%まで, または判定不 能では自覚無効, 点数が増加したときは自覚悪化とし た.

(2) 他覚的所見

以下 4 つの検査を他覚的変化の評価とした.

a. 残尿量：残尿が $50 \mathrm{ml}$ 以上（カテーテル留置例も 含む）で50\%以上の減少したとき，残尿量改善. 上の 条件を満たさないが，明らかに残尿が減少したとき， 残尿量やや改善. それ以外を無効とした。

b. 尿流量測定 (uroflowmetry 以下, UFM)：Siroky の方法に従い9), 最大尿流量ないしは平均尿流量が “1SD”以上の増加をみたとき, UFM 改善, “0.5SD か ら1SD”までをUFM やや改善とした。

c. 前立腺触診

d. TRUS

両者のいずれかが $25 \%$ 以上縮小していれば大きさ改 
図 2 総合評価

\begin{tabular}{|c|c|c|c|c|c|}
\hline 自堂的所見 & $\begin{array}{l}\text { 著 } \\
\text { 効 }\end{array}$ & 有 & $\begin{array}{l}\text { 無 } \\
\text { 効 }\end{array}$ & $\begin{array}{l}\text { 悪 } \\
\text { 化 }\end{array}$ & 計 \\
\hline 改 & 8 & 3 & 1 & & 12 \\
\hline やや改善 & $1=$ & 0 & 1 & & 2 \\
\hline 不 & 10. & 6 & 3 & & 19 \\
\hline 悪 化 & & & & & 0 \\
\hline 計 & 19 & 9 & 5 & 0 & \\
\hline
\end{tabular}

\begin{tabular}{|c|c|}
\hline 有 用 & 12例 (37\%) - \\
\hline やや有用 & 11例 (33\%) - \\
\hline 有用でない & 10例 (30\%) \\
\hline
\end{tabular}

善，25\%以下の縮小であれば大きさやや改善とした。

以上の他覚的所見のいずれかが改善，または複数の やや改善の場合は他覚改善. いずれかがやや改善すれ ば他覚やや改善。改善せずまたは判定不能のときは, 他覚不変とした。検查上悪化がみられたら悪化とした。

（3）副作用

本治療施行により起ったと思われる症状はすべて記 載することにし，重篤な場合はただちに中止すること にした，また，その症例は完全例にはならないとして も, 副作用チェックの症例には加えることにした。

（4）総合評価（図 2)

自覚的，他覚的な変化の両者を合わせ，さらに副作 用も考慮にいれて TRPHT の総合評価を有用, やや有 用，有用でないの 3 群に分類した。すなわち，他覚改 善であり，自覚著効，自覚有効では“有用”。また他覚 やや改善で，自覚著効であれば“有用”とした。他覚 改善, 自覚無効のとき, 他覚やや改善, 自覚有効のと き，他覚不変，自覚著効のとき“やや有用”とした。 それ以外，または重篤な副作用が出現した場合は“有 用ではない”とした。 以上より有用率は有用とやや有 用を加え，全症例で除した值とした。

\section{III. 結 果}

平成元年 8 月より 8 カ月にわたり日本大学医学部板 橋病院泌尿器科に扮いて経直腸式前立腺温熱療法 （TRPHT）の登録例は48例である。そのうち，不適格 は 6 症例であり，適格例は42例となった，適格例の5
図 3 自覚症状スコアの変化（6 項目合計値）

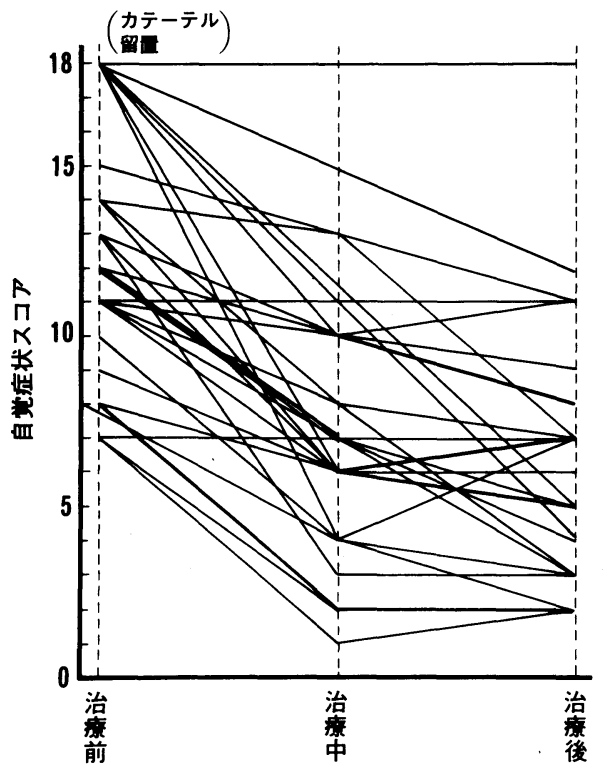

ち，9例は不完全例であり， 1 例は副作用で中止して いる．従って今回の評価できる完全例は33例となった が，副作用に関しては不完全例も加えた，完全例33例 の年齢は62歳から87歳，平均72歳であった。

自覚的症状の点数をみると, 施行前は 7 点から 18 点 におよび，9点以下は 9 例，10点から14点は 16 例， 15 点以上が 8 例. 平均点数は 12.3 点であった。この点数 の経過をみると, 5 回終了時では25例の点数が下降し， 平均点数は 6.5 点となった. 10 回終了時ではさらに下降 したのが13例で，残りは 5 回終了時と同様の点数で あった.しかし, 全症例の平均值は6.1点に下降した(図 3 ). 各症例ごとの自覚的効果は自覚著効は19例 $58 \%$, 自覚有効は 9 例 $27 \%$, 無効は 5 例 $15 \%$ となった（図 2).

他覚的所見としては他覚改善 12 例 $36 \%$, 他覚やや改 善 2 例 $6 \%$ ，不変19例 $58 \%$ であった。また，それぞれ の諸検査別の改善の程度をみると，施行前後で残尿量 を測定した 23 例中, 残尿量 $50 \mathrm{ml}$ 以上は 15 例でそのらち 9 例で改善, 2 例がやや改善. 7 例中 6 例はカテーテ ル抜去ができている，UFM では前後で検査した17例 中 4 例改善, 2 例やや改善を示した。しかし, 直腸診, およびTRUS ではほとんど変化を示さず, 前立腺その ものが温熱により縮小したとは考えられなかった（図 2 ).

副作用に関しては, 軽症を含めると肛門部の疼痛 4 例，全身および局所の熱感 2 例，血尿 2 例で，42例中 
8 例（19\%）の副作用の発生率であった。このらちで 重篤と考えられたのは肚門部疼痛を訴えた 1 例 ( $2 \%)$ のみで, 痔核の既往があり 2 回で中止した。その他, 膀胱刺激症状，尿道痛などはみられなかった。 また， 末梢血，生化学検査でも前後において変化した症例は みられなかった。

これらの結果をあわせ総合評価を行うと, “有用”は 33例中 12 例 $37 \%$, “やや有用”は11例33\%，“有用でな い”は10例30\%であった。これょり有用率は 23 例70\% を示した（図 2).

\section{IV. 考 察}

泌尿器科領域の悪性腫瘍に対する温熱療法は, 他の 領域のそれと同様に最近になって行われるようになっ

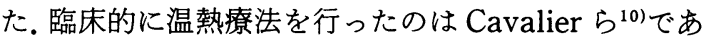
り，特に四肢の悪性腫瘍に対し局所血液潅流による温 熱療法の成績を発表した。しかし，その副作用から制 限された癌にのみ用いられるべきものであり，内臓の 癌には適応とはならなかった。一方, 膀胱腫瘍は袋状 の藏器であり, 温水を注入しても他の臓器を障害せず に膀胱内の腫瘍を加温することが可能である。ぞのた め，諸外国 ${ }^{11121}$ 拈よび本邦 ${ }^{13144}$ に扮いて子種々の工夫 をこらした報告がなされた。しかし，浸潤癌には無効 なことから，その適応は限定されたものとなった。そ の後, 深部加温の可能な極超短波や $\mathrm{RF}$ 波を用いた加 温器が登場し, 深部癌でも治療することが試みられる ようになった。中嶋ら ${ }^{15}$ も $\mathrm{RF}$ 波温熱治療器にて進行 性尿路性器癌を治療し, 放射線治療との併用により効 果をあげることができたとのべている.

前立腺は体表からは遠いが，直腸とは相接している 臓器である．そのことから前立腺に対する操作は以前 より経直腸的に行われることが多い。これと同様に経 直腸的に前立腺を加温して前立腺癌の治療を行うこと が試みられた。平井ら ${ }^{16)}$ は $13.5 \mathrm{MHz}, \mathrm{RF}$ 波発生温熱 治療器を用いて, VP-16, Peplomycin を併用して 7 例 の前立腺癌の治療を行った。 6 例に腫場の縮小がみら れたが，副作用として 1 例に下腹部の火傷を認めたと い5. YerushaImi ら ${ }^{5}$ は15例の前立腺癌に対し2.45 $\mathrm{GHz}$ の温熱治療器にて週 2 回の温熱療法単独ないし は放射線療法，ホルモン療法の併用を行った。その結 果, 全例合併症はなく, 腫瘍縮小, 局所疼痛の改善, 尿閉のためカテーテル留置していた患者はカテーテル 拔去できたという。ささらに, YerushaImi のその後の報 告では, 同様の方法で32例の前立腺癌に試み, 長期 follow upの結果では生存率を延長することができな
かったとのべている6). しかし, 週 2 回, 1 時間の温熱 療法にて, 尿路閉塞症状の改善が著しかったこと, ま た腫瘍の縮小がみられたことは温熱療法は前立腺癌の みならず, 前立腺肥大症の尿路閉塞症状に対しても有 効ではないかと考えられた。

その後, 組織透過性がよい $915 \mathrm{MHz}$ を発生する機器 が開発された.プロスタサーマー99Dである. Lindner $ら^{17)}$ は 6 例の尿閉となった前立腺肥大症に対して同様 の条件で温熱療法を行った。 6 例中 5 例はカテーテル 抜去でき，6 月月間は良好であったが，前立腺の大き

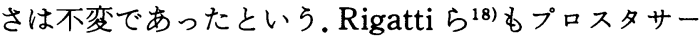
マーを用いてカテーテル留置中の前立腺肥大症19例, 前立腺癌 6 例, 計25例に対して温熱療法を行った。こ れらのらち尿路閉塞症状は $70 \%$ に改善し， 25 人中 18 人 はカテーテル free となった. その18人のうち13人は前 立腺肥大症であった。ささらに尿流測定を行った結果， 70\%に明らかな改善をみており, 残尿の減少も75\%に 認められた. YerushaImi らの29例の分析では昼間頻 尿, 夜間頻尿, 逼迫感, 尿流, 遷延度が改善し，カテー テル留置中の 11 人中 8 人が抜去可能となったという. われわれの症例でも 7 例中 6 例にカテーテル拔去が可 能であった。

今回用いたプリモスはベルギー，テクノマティクス 社にて開発された機器であり，基本構造はプロスタ サーマーとほぼ同様である。プリモスも $915 \mathrm{MHz}$ の極 超短波を発振し，アプリケータ，冷却装置などを有し ている、また，本論でのべた方法は週 2 回，1時間の 加温である。この理由は, 温熱耐性は heat shock protein (HSP) と関係があるといわれ，HSP は温熱後か ら72時間まで存在すること，そのため 3 日ごとに行え ば温熱耐性を回避することができるからである ${ }^{19)}$. 自 覚症状の評価に関しては YerushaImi は独自の点数》) を用いているが，われわれは自覚症状 6 項目に点数を 与える方式を試みた。この 6 項目はそれぞれが独立し た要素であることが望ましいが，現時点ではこの方式 で点数を算定した，他覚所見としては，種々の諸検査 による客観的結果が得られることが望まれた。しかし， 外来通院での患者に，ことごとく検査することが不可 能であるため, 検査未施行の個所があり, “他覚不変” にならざるを得なかった。また，自覚，他覚，副作用 を合わせた総合評価方式の基準にも問題が残されてい る。しかし，“有用”は37\%。“やや有用”は33\%とい 万数字は, 臨床上よく効いたといらのが 3 人に 1 人, 効いたといらのがやはり 3 人に 1 人といら印象とほぼ 
一致した結果であり，それ故今回の評価法は正しいと 考えた。

本法を施行するに際して, 副作用のチェックも重要 である. 今回の経験から, Servadio ら ${ }^{20)}$ のべている ごとく，特に痔などの肛門，直腸疾患，ないしは既往 を有する場合には禁忌であると考える．今回の有用率 を考慮すると，この局所温熱療法は前立腺肥大症に対 して比較的無侵襲に治療することょり，心血管系，脳 血管系な打の重篤な合併症を有する患者には有効な治 療法となりらることが判明した。

それでは温熱療法が前立腺疾患の尿路閉塞症状を軽 減するそのメカニズムは何なのであろらか，癌細胞は 温熱に感受性があり, 温熱により变性壊死となり, 癌 組織が縮小することは明らかにされている。しかし， 前立腺肥大症の上らな良性疾患にも有効であることを 証明するためには, 細胞レベルでの解明が必要である。 Leib ら ${ }^{21)}$ は犬の前立腺に温熱を加えたのち, 組織学的 に観察した。これにより，間質に単核球の浸潤，腺上 皮に多核球の浸潤を認めたという。しかし，これらの 変化は非特異的な反応であり, 問題の解決にはなって いない，実際，前立腺肥大症のときの排尿障害の機構 はいまだ不明のことが多い, $\alpha$-adrenergic nerve fiber が関係していることは事実であり， $\alpha$-blocker が症状 改善に有効であることは認められている。それ故, 温 熱療法も $\alpha$-adrenergic receptor に関係しているとも 想像される. 今後, この方面のみならず, 細胞レベル での研究により前立腺肥大症に対する温熱の効果のメ カニズムが解明されていくことが期待される.

\section{V. 結 語}

1. 前立腺温熱治療器 “プリモス”を用い前立腺肥大 症に対して経直腸式前立腺温熱療法を行い，33例の自 覚的症状, 他覚的所見の变化より, その効果を客観的 に評価することを試みた。

2. 自覚的症状に関しては各症状に点数を与光, 施行 前後での変化を記載した。その結果，著効 $58 \%$ ，有効 27\%，無効15\%であった。

3. 他覚的には改善 $36 \%$, やや改善 $6 \%$, 不変 $58 \%$ で あった．しかし，前立腺の大きさに变化はなく，縮小 はみられなかった。

4. 温熱療法による副作用として主なものは肛門部 の疼痛である，そのため，直腸，肚門疾患を有する症 例は避けるべきである。

5. 総合評価では有用 $37 \%$, やや有用 $33 \%$, 有用率は 70\%であった。
6. 以上より, 温熱療法は前立腺肥大症の非観血的治 療としては有効な手段であり, 特に合併症を有する高 齢者の患者には適応と考えた。

\section{文献}

1）岡田清己：癌に対する温熱療法, 医学のあゆみ, 107, 319-395, 1978.

2) Levine, E.M. and Robbins, E.B.: Differential temperature sensitivity of normal and cancer cells in culture, J. Cell. Physiol., 76, 373-379, 1970.

3）清滝修二：ラット正常拉よび担癌膀胱における温 熱療法の組織血流に及ぼす影響一水素ガスクリア ランス法による血流測定一, 日泌尿会誌, 79, 287-296, 1988.

4）岡田清己, 清滝修二, 川添和久, 佐藤安男, 田原亮 一, 木下正之, 熊谷振作, 北島清彰, 尾上泰彦, 滝 本至得, 岸本 孝: 膀腅腫場に対する温水療法の 研究(第 2 報)，日泌尿会誌，68，128-135，1977.

5) Yerushalmi, A., Servadio, C., Leib, Z., Fishelovitz, Y., Rokowsky, E. and Stein, J.A.: Local hyperthermia for treatment nf carcinoma of the prostate; A preliminary report, The Prostate, 3, 623-630, 1982.

6) Yerushalmi, A., Shani, A., Fishelovitz, Y., Arielly, J., Singer, D., Levy, E., Katsnelson, R., Rakowsky, E. and Stein, J.A.: Local microwave hyperthermia in the treatment of carcinoma of the prostate, Oncology, 43, 299-305, 1986.

7) Yerushalmi, A., Fishelovitz, Y., Singer, D., Reiner, I., Arielly, J., Abramovici, Y., Catsenelson, R., Levy, E. and Shani, A.: Localized deep microwave hyperthermia in the treatment of poor operative risk patients with benign prostatic hyperplasia, J. Urol., 133, 873-876, 1985.

8) Reddy, P.K., Wasserman, N., Castaneda, F. and Castaneda-Zuniga, W.R.: Balloon dilatation of the prostate for treatment of benign hyperplasia, Urol. Clin. North Amer., 15, 529-535, 1988.

9) Siroky, M.B., Olsson, C.A. and Krane, R. J. : The flow rate nomogram: I. Development, J. Urol., 122, 665-668, 1979.

10) Cavaliere, R., Ciocatto, E.C., Giovanella, B.C., Heidelberger, C., Johnson, R.O., Margotini, M., Mondovi, B., Moricca, G. and Rossi-Fanelli, A. : Selective heat sensitivity of cancer cells. Biochemical and clinical studies, Cancer, 20, 1351 $-1381,1967$.

11) Hall, R.R., Shade, R.O.K. and Swinney,J. : Effects of hyperthermia on bladder cancer, Brit. 
Med. J., 15, 593-594, 1974.

12) Lunglmayr, G., Czech, K., Zekert, F. and Kellner, G.: Bladder hyperthermia in the treatment of vesical papillomatosis, Int. Urol. Nephrol., 5, 75-84, 1973.

13）岡田清己, 権 秉震, 野垣譲二, 新村武明, 斎藤忠 則, 天谷龍夫, 山本忠男, 清滝修二, 佐藤安男, 小 川成海, 森田博人, 北島清彰, 岸本 孝: 塝腅腫場 に対する温水療法一ウロキナーゼ併用療法一, 西 日泌尿，42，967-971，1980。

14）北島清彰, 吉田利夫, 岡田清己, 岸本 孝, 高橋克 俊：PS (Peplomycin-Silicone) 弾頭カテーテル を用いた膀脂腫瘍の温水療法一Cepharanthin 併 用療法一, 癌と化学療法, 11，2520-2525，1984.

15）中嶋和喜, 久住治男, 山本 肇, 内藤克輔, 三崎俊 光, 小橋一功, 横山 修, 斉藤泰男: 手術不能の進 行泌尿性器悪性腫瘍に対する $8 \mathrm{MHz}-\mathrm{RF}$ 加温療法 の研究(第 2 報), 日泌尿会誌, 77, 304-309, 1986.

16）平井正孝, 中野 優, 牛山知己, 増田宏昭, 太田信 隆, 田島 嵉, 河辺香月, 阿曾佳郎：前立腺癌に対 する温熱療法の試み, 日泌尿会誌, 79, 1761-1764, 1988.

17) Lindner, A., Golomb, J., Siegel, Y. and Lev, A. :
Local hyperthermia of the prostate gland for the treatment of benign prostatic hypertrophy and urinary retention. A preliminary report, Brit. J. Urol., 60, 567-571, 1987.

18) Rigatti, P., Guazzoni, G., Maffezzini, M., Colombo, R., Montorsi, F. and Consonni, P.: Local deep microwave hyperthermia in the treatment of prostatic diseases, Arch. It. Urol., 61, 179 $-181,1989$.

19）平方 化, 清水一史, 小野魁, 岡田清已: 熱 ショック蛋白質の細胞内蓄積と翻訳系の温熱耐性 の獲得, 日大医誌，49，281-292，1990.

20) Servadio, C., Lindner, A., Lev, A., Leib, Z., Siegel, Y. and Braf, Z.: Further observations on the effect of local hyperthermia on benign enlargement of the prostate, World J. Urol., 6, 204-208, 1989.

21) Leib, Z., Rothem, A., Lev, A. and Servadio, C. : Histopathological observations in the canine prostate treated by local microwave hyperthermia, The Prostate, 8, 93-102, 1986.

（1990年12月 18 日受理） 